\title{
SELECTED TOPICS WITH RESPECT TO THE FREEHOLD OIL AND GAS LEASE TOP LEASE, ESTOPPEL AND SHUT-IN ROYALTIES
}

\author{
J. FORBES NEWMAN AND TERRANCE M. HUGHES*
}

\begin{abstract}
There are obviously a great number of issues which could be addressed in a paper dealing with the freehold oil and gas lease. Our paper will be limited to a discussion of three of these issues: 'first, the practice of top leasing and selected problems relating thereto, secondly, the question of estoppel as a method of reviving an otherwise terminated lease and thirdly, shut-in royalty payments focusing on when such a payment is required to be made in order to extend the term of the lease and the conditions which must be present before such a payment may be validly tendered.
\end{abstract}

\section{TOP LEASE}

\section{A. INTRODUCTION}

Although there is a considerable amount of jurisprudence and literature on the subject of top leasing in the United States, very little has been written on the subject in Canada. ${ }^{1}$ Nevertheless, top leasing is a common occurrence in the oil patch in Western Canada. Ethical and moral concerns over whether anyone should engage in top leasing, and which led one American court in 1960 to state that "[t]op leasing has the same invidious characteristics as claim jumping"'2 seem to have lessened considerably as more and more companies have become involved in the practice. Generally speaking, top leasing is now viewed as a legitimate business practice in a competitive marketplace. Although most of the jurisprudence in the area of top leasing is American, the issues which these cases raise provide some fruitful grounds for examining the practice of top leasing in Canada. It is proposed to deal with selected problems in this area which have been examined by American courts, looking at these problems from a Canadian perspective.

A top lease has been defined by the Supreme Court of Canada as being a lease "which takes effect upon the termination of a prior existing lease" ${ }^{3}$ One American writer describes a top lease as "a partial alienation of a possibility of reverter". ${ }^{4}$ In Canada, where the more favoured route is the option to acquire a top lease, the interest an optionee acquires has been described as being an option to acquire a profit à prendre in the future contingent upon the extinguishment of the existing exclusive profit à prendre granted by the lessor. ${ }^{5}$ The comment is made that when the op-

* Solicitors, Ballem, McDill and MacInnes, Calgary, Alberta.

1. J. B. Ballem, The Oil and Gas Lease in Canada, (1973) 231, J. F. Curran, E. R. Grant, "Effect of Amendments to Petroleum and Natural Gas Leases" (1965-1966) 4 Alta. L. Rev. 267.

2. Frankfort Oil Co. v. Snakard 279 F. (2d) 436 at 445 n. 23 (10th Cir 1960).

3. Meyers v. Freeholders Company Limited and Canada Permanent Trust Company [1960] S.C.R. 761 at 766.

4. M. L. Brown "Effect of Top Lease: Obstruction of Title and Related Considerations", (1978) 30 Baylor L. Rev. 213 reprinted in (1979) Problems Arising under the Oil and Gas Lease, (Mosberg, L. G. Ed.) 128. Note the lessor has not parted with his entire interest and thus a lessee under a top lease acquires the lessor's possibility of reverter in that what he has will become a fee simple determinable interest upon expiration of the bottom lease.

5. Curran \& Grant, supra n. 1 at 278. 
tion is exercised the interest of the top lessee is presently vested although, if the existing exclusive profit à prendre has not terminated, the use and enjoyment of the new grant is automatically postponed until the extinguishment of the existing exclusive profit à prendre. However one approaches the problem, it is clear that a top lease or an option to acquire a top lease makes the reversionary interest of the lessor subject to the right of the optionee or the top lessee to acquire a lease.

There are three generally accepted methods of acquiring a top lease. First, the top lessee may acquire a conditional lease, which is basically a standard form petroleum and/or natural gas lease which is expressly conditional upon the termination of the prior "bottom lease"'. Secondly, the top lessee may acquire a right of first refusal from the lessor exercisable upon the lessor receiving a bona fide offer to lease its petroleum and natural gas rights. Thirdly, a potential lessee may acquire an option to acquire a top lease which option might be exercisable at any time but would only become effective upon the termination of the bottom lease. Looking at the situation from the top lessee's standpoint, the option route appears to be the most generally acceptable, mainly because of its greater flexibility in terms of when bonus payments are payable. A conditional lease automatically becomes binding upon the top lessee when the bottom lease terminates and at that point the top lessee becomes obligated to pay stipulated bonuses and to assume all obligations. The right of first refusal approach seems the least acceptable route, because it requires the positive act of some other party, i.e. a bona fide of fer received by the lessor from a third party.

Disputes in the United States have frequently arisen between the bottom lessee and top lessee over the ownership of the leasehold estate and generally focus on the question of whether or not the bottom lease has expired or has been extended. Actions have been brought by the bottom lessee to establish the validity of his lease or have been brought by the top lessee with or without the assistance of the lessor for a declaration that the bottom lease has terminated and that the top lease is the valid lease. In any event, the question ultimately becomes which of the bottom or the top lease is the valid lease.

Although there are a number of aspects of top leasing which could usefully be discussed, this paper will be restricted to an analysis of two areas only, specifically (1) whether the very act of granting a top lease by the lessor could be used by a bottom lessee as a means of extending the term of a bottom lease thus rendering the top lease void, and (2) whether a top lessee could be found liable in trespass to a bottom lessee in the event that, following drilling activity by a top lessee, the bottom lease was ultimately found to be the effective lease. Although no Canadian authority has been found which is directly on either point, the extensive American case law and literature may provide some useful guidelines for Canadian oil companies engaged in top leasing.

\section{B. OBSTRUCTION OF TITLE}

Under the American doctrine of obstruction, a lessor is not permitted to assert that the lease has terminated or otherwise come to an end for failure on the part of the lessee to produce oil or gas or otherwise to com- 
ply with the terms of the lease if the lessor has obstructed the operations of the lessee, and such obstruction accounts for the failure of the lessee to comply with the terms of the lease. In order for the obstruction to have such an effect, the situation must be one where the lessee could otherwise have complied with the terms of the lease. ${ }^{6}$

There are two major American decisions from Oklahoma dealing with the question of whether the creation of a top lease constitutes an obstruction of the bottom lessee's title. In Simons v. McDaniel, ${ }^{7}$ the Court held that the bare existence of a top lease constituted an obstruction of the bottom lessee's title thereby entitling the bottom lessee to a reasonable extension of its lease term during which to obtain production. In Rorex v. Karcher ${ }^{8}$ it was held on the other hand that a properly drafted top lease is valid and does not constitute an obstruction of title. It is generally accepted that Rorex is a better statement of American law. ${ }^{9}$

In Simons, the lessor granted to the bottom lessees (the plaintiffs) a five-year lease which provided that the lease would terminate if no well had been commenced before the end of the primary term, subject to the lessee's right to make delay rental payments. Shortly before the primary term expired, a top lease was granted covering the same lands, to become effective two weeks after the bottom lease's primary term had expired. The bottom lessees commenced a well just before the term expired and brought an action to quiet title in order to eliminate the top lease as a cloud on their title. They also sought a court order permitting them to cease drilling operations until the dispute had been resolved. With respect to the question of the top lease, the Court held that the very act of the lessors in executing and delivering the top lease amounted to an election to declare the first lease at an end. The Court noted:10

These acts obstructed the exercise of the rights of the original lessees under the terms of their lease. Their title was clouded. Had they produced oil or gas as a result of com. menced development, ownership thereof would have been in litigation and the value of production impounded, so that a real obstacle is imposed by the lessors upon the right of lessee plaintiffs.

The Court in Simons permitted the bottom lessees, who were found to be acting in good faith, to suspend operations until the question of obstruction had been determined."1

In Rorex, the plaintiff top lessee acquired a top lease while a valid oil and gas lease was in existence. Shortly before the prior lease expired, the lessors granted an extension to the bottom lessees, extending the bottom lease. The bottom lessees commenced drilling after their primary term had expired. The top lessees sued when the bottom lessees refused to stop drilling and at trial the bottom lessees successfully called into question the validity of the top lease. The Supreme Court of Oklahoma overturned the trial decision and the judgment provided in part as follows: ${ }^{12}$

6. 2 E. O. Kuntz, A Treatise on the Law of Oil and Gas (1977) 324.

7. 7 P. (2d) 419 (Okla. 1932).

8. 224 P. 696 (Okla. 1923).

9. J. H. Kemp, “Top Leasing for Oil and Gas: The Legal Perspective”, (1983) 59 Den. L. J. 641, and supran. 4.

10. Supra n. 7 at 420.

11. Supra n. 7 at 421. See also Robinson v. Continental Oil Company 255 F. Supp. 61 (1966).

12. Supran. 8 at 697. 
... it is the contention of the defendants that the lease to the plaintiff, having been executed while there was a valid lease on the property, was void. No authority is cited to sustain this proposition, and we have been unable to find any which tends to support the same. The lessors were the owners of the fee-simple title to the property, and the same was not restricted in any manner whatever. Such being the condition of the title, there was no reason why the owners of the fee could not carve out as many estates as they saw fit. There was no reason why the Jacksons could not execute a second oil and gas lease during the existence of the first lease. Of course, the holders of the second lease would take same subject to the rights of the holders of the first lease . . . We are therefore of the opinion that the lease to the plaintiff was valid, and that judgement should have been rendered for the plaintiff.

Only rarely, therefore, have U.S. courts held that the simple act of taking a top lease constitutes an obstruction or cloud on title thus extending the term of the bottom lease. Generally, obstruction requires an action more unequivocally hostile to the lessee's title, such as physical exclusion from the leased property, filing suit, demanding a release, a recital in a top lease that the bottom lease has expired, or a combination of these. ${ }^{13}$ Nevertheless, U.S. writers on the subject, perhaps in light of the conflict in the case law, conclude that a top lease must contain language which explicitly subordinates it to an existing bottom lease and that it is not possible for a lessor to grant a presently effective "naked" top lease which does not acknowledge the existence of the prior lease and which is created while the prior lease is still in effect. Such a grant may be viewed as an attempt to obstruct operations under the bottom lease thereby excusing performance by the bottom lessee and perpetuating the bottom lease during the period that the obstruction continues.

There is no comparable doctrine of obstruction in Canadian oil and gas jurisprudence. One should consider, nevertheless, whether the granting of a top lease that purported to be immediately effective might be construed as a breach of the lessor's covenant for quiet enjoyment. As frequently drafted, the "standard" covenant of quiet enjoyment contains language that the lessee "shall and may peaceably possess and enjoy the same and the rights and privileges hereby granted during the said term and any extension thereof without any interruption or disturbance from or by the Lessor or any other person whomsoever". Such language implies that the lessor will not do or be a party to any action which limits or interferes with the ability of the lessee to perform its obligations under and to enjoy the benefits of the lease.

Since the covenant for quiet enjoyment comes from general landlord and tenant law, one presumably would look there for guidance as to how its principles would apply. As there is no existing Canadian jurisprudence directly on point to give such guidance, it is only possible to pose questions as to what conclusions would be reached. Would the granting of a "naked" presently-effective top lease constitute the kind of interference required to constitute a breach of the covenant? There appears to be some uncertainty as to the degree of physical interference required, if any, to constitute a breach of the covenant. ${ }^{14}$ In the event that the grant

13. Supran. 4 at 130, and also note Shell Oil Co. v. Goodroe 197 S.W. (2d) 395 (Tex Civ. App. 1946) (lessor's executed top lease, gave notice repudiating bottom lease and asked bottom lessee to execute a release while the bottom lease was still in effect - in the aggregate their actions excused bottom lessee of operating gas well while the dispute was dealt with).

14. Williams \& Rhodes, Canadian Law of Landlord and Tenant (5th ed.) 9:1:3. 
of the top lease was considered to be a breach, would the breach entitle the bottom lessee to refuse to pay delay rentals or to perform other obligations under the bottom lease? Applying ordinary landlord and tenant principles, it is difficult to be conclusive, as the remedies for breach in a normal landlord-tenant situation (one of which is the suspension of the obligation to pay rent) may not necessarily apply in an oil and gas lease situation.

Nevertheless, the granting of a "naked" top lease would appear to constitute a direct challenge to the status of the bottom lease, and a top lessee would be well advised to avoid any potential problem by taking appropriate precautions.

It is equally important to have the top lessee acknowledge that the top lease will not become effective until the termination of the bottom lease in order to avoid the potential pitfalls of the top lease being characterized as a concurrent lease. If a lessor is obligated under an existing lease and makes another currently ef fective lease upon the same leased premises for a term less than, equal to or greater than the existing lease, the second lease may be characterized as a concurrent lease resulting in the second lessee being entitled to receive the rents and to enforce the covenants of the earlier lease, thus replacing the original lessor in the first lease. ${ }^{15}$ As both a properly drafted top lease and an option to lease would probably be characterized as a future lease rather than a concurrent lease which is presently effective, the problem should not arise. Nevertheless, caution is advised and failure to make it clear that the top lease will not be effective until the bottom lease has terminated might have unintended results.

Provided the top lease recognizes the existence and priority of the bottom lease by an express provision that it is subject to the bottom lease and will not become effective until the bottom lease has terminated, and provided that neither the top lessee nor the lessor otherwise assert that the top lessee's rights are superior to those of the bottom lessee, it is unlikely that a Canadian court would hold that the mere existence of the top lease constituted an obstruction of the bottom lease or a breach of the covenant for quiet enjoyment. Since the Canadian experience seems to use the option to lease route more frequently than the conditional lease, care should be taken to provide both in the option agreement itself and in the lease to be granted that, notwithstanding the exercise of the option prior to the termination of the bottom lease, the top lease is specifically subject to the bottom lease and will not be effective until the bottom lease has terminated.

\section{TRESPASS}

Where exploration or drilling operations are conducted under a top lease that subsequently is found to be invalid because of the continuing validity of the bottom lease, courts in the United States have found the top lessee to be liable for damages in trespass to the bottom lessee. As well, a bottom lessee may be found liable in trespass to a top lessee where the top lease is subsequently found to be valid notwithstanding that the bottom lessee has continued to take production under the terminated bot-

15. Id. at 3-58. 
tom lease. Generally speaking, these cases have arisen in situations where a top lessee erroneously believes that the bottom lease has expired, whereas in fact the term has been extended either through pooling, via the commencement of drilling operations or by production prior to the expiration of the lease or otherwise.

One major U.S. case in this area, Swiss Oil Corp. v. Hupp, ${ }^{16}$ was a Kentucky case involving a claim for damages by a bottom lessee against a top lessee where the top lease was held to be invalid. The major point to be decided was whether the top lessee was a "wilful" or an "innocent" trespasser. The Court, in noting that the burden would always be upon the trespasser to establish his status as an innocent or mistaken invader of another's property and that the test to be applied would be that of intent, specifically commented as follows: ${ }^{17}$

The conditions and behavior are usually such that the Court can determine whether the trespass was perpetrated in a spirit of wrongdoing, with a knowledge that it was wrong, or whether it was done under a bona fide mistake, as where the circumstances were calculated to induce or justify the reasonably prudent man, acting with a proper sense of the rights of others, to go in and to continue along the way.

Various factors were taken into consideration in establishing good faith including:

(a) at least reasonable doubt of the other party's exclusive or dominant right, and

(b) the top lessee acted upon the advice of reputable counsel to whom all facts had been fairly submitted upon questions of legal right concerning which a layman could hardly have knowledge.

The Court noted that the test was not the trespasser's violation of the law in the light of the maxim that every man knows the law, but was the question of his sincerity and his actual intention at the time. Taking all these matters into account, the Court affirmed the decision of the trial court that the top lessee was an innocent trespasser.

It was then necessary to consider the question of damages. The bottom lessee was seeking recovery of "gross receipts" of the oil produced by the top lessee on the assumption that the top lessee was a wilful trespasser. In view of the fact that the top lessee was found to be an innocent trespasser, the Court determined that damages would be the value of the oil at the mouth of the well less the amount reasonably expended in producing it. The conclusion was that the bottom lessee was entitled to the top lessee's net profits - i.e. the value of the oil at the mouth of the well as established by the sale price less reasonable costs and expenses of production. ${ }^{18}$ The validity of some of the claimed deductions was contested by the bottom lessee. The Court ultimately rejected the top lessee's attempt to deduct the value of improvements, income taxes and legal fees and also held that the bottom lessee was not entitled to recover interest. ${ }^{19}$

16. 69 S.W. (2d) 1037 (Ky. 1934).

17. Id. at 1041 .

18. Id. at 1043-1044.

19. Id. at 1045-46. 
One further case in Kentucky, Joyce v. Zachary, ${ }^{20}$ once again upheld the liability of the top lessee to the bottom lessee for net profits, but allowed the top lessee to claim the following deductions:

(a) waterflooding expenses,

(b) ad valorem taxes,

(c) overpayment of landowner's royalties,

(d) operating expenses after the suit had been filed, and

(e) expenses for drilling a dry hole.

The Court refused to allow the top lessee to claim "supervisory" expenses of one of its non-participating partners. ${ }^{21}$

Once again, there is no Canadian authority directly on point. It is our opinion, however, that similar principles would apply in view of English and Canadian authority dealing with the question of trespass in mining and logging situations. Under the English common law, when trespass involved the wrongful taking of coal, it has been held that the measure of damages will vary accordingly as the trespass is committed deliberately. Where deliberate trespass is established, the measure of damages is held to be the value of the coal at the pithead, less the cost of raising coal to the surface but without making any allowance to the trespasser for the cost of getting and severing the coal. Where the trespass has not been considered to be wilful, a milder form of the rule has been applied and the trespasser is only liable for pithead value of the coal, less the cost of raising as well as the cost of getting and severing the coal. This milder rule is generally applied where the trespasser believes in good faith that he was likely to obtain a lease of the coal, when the true owner stood by and allowed his coal to be worked and where the trespasser was not deliberately working the coal with the intention of defrauding the true owner of the proceeds. 22

In Canada, the principles enunciated in the English mining cases have been applied as well in trespasses involving gold mining claims. In Lamb v. Kincaid, following a favourable judgment by the Gold Commissioner with respect to the boundary between contiguous placer mining locations and while an appeal therefrom was pending, the defendants, with the knowledge of the plaintiffs, entered upon the location and removed a quantity of auriferous material from the disputed and undisputed portions thereof, intermixed the products without keeping any account of the quantities taken from these respective portions and appropriated the gold recovered from the whole mass. Both the trial judge and the Supreme Court of Canada concluded that the plaintiffs were entitled to recover for the total value of the gold estimated to have been taken from the disputed portion of the claim without any deduction for the necessary expenses of working and winning the gold. ${ }^{23}$

20. 434 S.W. (2d) 659 (Ky. 1968).

21. Id. at 661-63.

22. Clerk \& Lindsell on Torts (15th ed.) 1126 (para. 22-45) and cases referred to therein, particularly Trotterv. MacLean (1879) 13 Ch. D. 574.

23. Lamb v. Kincaid (1907) 38 S.C.R. 516. See also Boyle Concessions v. Yukon Gold Co. (1920) 50 D.L.R. 742; Yukon Gold Co. v. Boyle Concessions(1914) 19 D.L.R. 336. 
Duff J., acknowledged the English decisions dealing with coal mining trespass and held that such principles would be equally applicable with respect to a trespass upon a placer mining claim. On the facts, it was found that the trespass was wilful. In determining the issue, it was found that a number of questions needed to be answered and that "the existence or non-existence in the mind of a trespasser of a belief in his title to the locus is not necessarily conclusive". ${ }^{24}$ The question was whether the defendant had a bona fide belief that he had the right to do what he did.

The Court was also required to look at the question of whether the owner, who was aware of the trespass, had disentitled himself to relief because he had stood by passively while the trespass proceeded. In the circumstances, it was found that the owner had not done so, but the principle was clearly recognized that, in other circumstances, the trespasser might have been entitled to claim the expenses of removing and washing the gold. ${ }^{25}$

Similar principles have been extended to other areas, in particular to the cutting of timber. Wasson v. California Standard Co. ${ }^{26}$ involved a situation where, in the course of wilfully and deliberately trespassing on the plaintiff's property in order to conduct a geological survey, the defendants damaged and destroyed a number of trees which otherwise would have been available to the plaintiff to cut down and sell as fence posts. The trial judge awarded damages to the plaintiff for the trees on the basis of their value as posts. An appeal was taken on the grounds that the trial judge had failed to make any allowance for what would have been the cost to the plaintiff of cutting the trees into posts. The Court of Appeal upheld the trial decision and stated that, where a trespasser acts wilfully and without color of right, as distinct from erroneously and in good faith, the value of the timber after cutting is the measure of damages and, accordingly, the trespasser would not be allowed any reduction for the cost of cutting or manufacturing the timber into posts.

Although oil and gas trespass has not been specifically addressed by Canadian Courts, the question of accounting for oil and gas production and the liability for the cost of drilling a well where an oil and gas lease terminates involuntarily has been dealt with. In Sohio Petroleum Company v. Weyburn Security Company Limited, ${ }^{27}$ which will be discussed at length subsequently in this paper, Sohio was required to account to Weyburn for the benefits from production received by it after the date of service of the writ of summons upon it, which was also the date when it had received from the sale of production more than the amount it had expended to acquire the production. Effectively, Sohio

24. Id. at 527.

25. Id. at 537. Also see Kirkpatrick v. McNamee (1905) 36 S.C.R. 152 where the Supreme Court of Canada adopted the milder rule and allowed the defendant to deduct the full cost of removing the gold.

26. (1965) 47 D.L.R. (2d) 71.

27. [1971] S.C.R. 81. See also two early Ontario decisions, Maple City Oil and Gas Co. v. Charlton (1912) 7 D.L.R. 345 (Ont. H.C.) and Mclntosh v. Leckie (1906) 13 O.L.R. 54, both of which allowed a lessee who drilled a well on a lease which was subsequently found to be invalid to deduct the cost of drilling the well when accounting to the lessor for production. 
was treated as an innocent trespasser and was entitled to deduct the costs of drilling the well. In Republic Resources Limited v. Ballem, ${ }^{28}$ a similar claim to recover the cost of drilling the well was disallowed and the Weyburn decision was distinguished on the basis that Weyburn, subsequent to the drilling date, had knowledge of the lessee's drilling activity and had accepted royalty and other monetary benefits as well as requesting the lessee to drill an offet well, which request was complied with. In the Republic'decision, the lessor had no knowledge that the well had been drilled until it was completed and had made no demands on the plaintiff and there was no subsequeni acquiescence or adoption of the benefit on the part of the lessor. In addition, in Weyburn there was production from which an accounting could be made, while in Republic the well was shut-in and there was none. Although it is difficult to draw general conclusions from these cases, the results apparently depend on the "equities" in each case, and it would appear that, if the Court feels. it would be inequitable for a party to receive the benefit of a well without paying compensation, it will apply broad equitable principles to require that compensation be paid.

In light of the Weyburn and Republic decisions, it is our opinion that the principles set forth in the American decisions dealing with trespass, as well as the principles set forth in the Canadian and English authorities involving mining trespass, gold mine placer claim trespass and timber trespass, would be applicable in Canada with respect to trespass situations involving a top lease and a bottom lease. If a top lessee drills a well and subsequently finds that the bottom lease has not expired, he will doubtless be found liable in trespass and the only questions will be whether he is a wilful or an innocent trespasser and whether he will be entitled, in accounting to the bottom lessee for the sale proceeds of the petroleum substances, to deduct the cost of drilling the well and of removing the petroleum substances and preparing them for sale. The American authorities suggest that to be characterized as an innocent trespasser, a top lessee should make a bona fide good faith effort to determine in advance of drilling whether the prior lease has terminated or whether the primary term has been extended by production or otherwise before entering onto the leased premises to explore or drill under the top lease. Such a good faith effort would no doubt include a title search as well as consultation with a knowledgeable oil and gas lawyer in order to obtain an opinion that the bottom lease has expired. Such a good faith attempt might also involve a careful surface examination of the lands in question to make sure that there has been or is no development and an attempt to determine whether any of the lands have been included in a pool or a unit which might have extended the lease.

\section{ESTOPPEL}

\section{A. INTRODUCTION}

It is well known that Canadian courts have interpreted the obligations of lessees under freehold oil and gas leases with respect to the payment of

28. [1982] 1 W.W.R. 692 (Alta. Q.B.). 
delay rentals and shut-in royalty payments very strictly. There have been situations where, notwithstanding the termination of the lease, both parties to the lease continue to act as though the lease was still effective, with the lessor continuing to accept delay rental payments, shut-in royalty payments, royalty payments or otherwise acting in a manner as though the lease was still alive. When the true state of affairs is discovered and the lessee discovers that the lease has terminated at some earlier date, he will often raise arguments based on equitable principles that the lessor, subsequent to the technical termination of the lease, by accepting royalty payments or by his actions acknowledging the existence of the lease, should be estopped from asserting the true legal position, i.e. that the lease has terminated.

There has been a considerable amount of case authority, particularly from the Supreme Court of Canada, as well as legal literature dealing with the problem. ${ }^{29}$ The general view appears to be clear that estoppel, except in the rarest of circumstances, can never be raised successfully as either a defence or a cause of action in order to assert the revival of the otherwise terminated lease. A recent decision of the Alberta Court of Appeal, Voyager Petroleums Ltd. v. Vanguard Petroleums Ltd., Canada Permanent Trust Company and Canadian Imperial Bank of Commerce, ${ }^{30}$ suggests that the question of estoppel deserves to be considered once again. Notwithstanding the case authority dealing with estoppel and the general negative approach of the Courts, there has always been a nagging feeling at the back of many lawyers' minds that given the appropriate circumstances estoppel could be successfully argued to revive a terminated lease.

\section{B. TYPES OF ESTOPPEL}

The law of estoppel has evolved significantly in the last thirty years. The main types of estoppel that have been raised in oil and gas situations are estoppel by representation, promissory estoppel, estoppel by acquiescence and estoppel by deed.

Estoppel by representation, perhaps the classic form of estoppel, has been described as follows: ${ }^{31}$

Where one person (the "representor") has made a representation to another person (the

"representee") in words or by acts and conduct, or (being under a duty to the representee to speak or act) by silence or inaction, with the intention (actual or presumptive), and with the result, of inducing the representee on the faith of such representation to alter his position to his detriment, the representor, in any litigation which may afterwards take place between him and the representee, is estopped, as against the representee, from making or attempting to establish by evidence, any aver-

29. Canadian Superior Oil Ltd. v. The Paddon-Hughes Development Co. Ltd. and Ralph Hambly [1970] S.C.R. 932, Sohiov. Weyburn supra n. 27, Ballem, supra n. 1 at 279-289, J. B. Ballem, "The Continuing Adventures of The Oil and Gas Lease" (1972) 50 Can. Bar. Rev. 423; R. J. Harrison, "Selected Cases, Legislation and Developments in Oil and Gas Law" (1972) 10 Alta. L. Rev. 391; J. H. Currie, "Recent Cases and Developments in Oil and Gas Law" (1971) 9 Alta. L. Rev. 452; R. T. Booth and R. P. Desbarats, "Recent Developments in the Law of Interest to Oil and Gas Lawyers" (1983) 21 Alta. L. Rev. 114.

30. [1983] 5 W.W.R. 622 .

31. Spencer Bower and Turner, The Law Relating to Estoppel by Representation (3rd ed. 1977) 4. 
ment substantially at variance with his form of representation, if the representee at the proper time, and in the proper manner, objects thereto.

One of the main limitations to establishing a case based upon estoppel by representation is the fact that the representation must be as to an already existing fact. Since many situations involving estoppel relate to representations as to future courses of conduct, the law of estoppel has evolved to include promissory estoppel, which was effectively made part of our modern law by the celebrated decision of Denning, J. in Central London Property Trust Ltd. v. High Trees House Ltd. and certain decisions which preceded and followed it. ${ }^{32}$

A succinct definition of promissory estoppel is given in Halsbury as follows: ${ }^{33}$

When one party has, by his words or conduct, made to the other party a clear and unequivocal promise or assurance which was intended to affect the legal relations between them and to be acted upon accordingly, then, once the other party has taken him at his word, and acted upon it, the one who gave the promise or assurance cannot afterwards be allowed to revert to their previous legal relations as if no such promise or assurance had been made by him, but he must accept their legal relations subject to the qualification which he himself has so introduced.

The breakthrough with respect to promissory estoppel was that it was now possible to use estoppel, primarily as a defence, in situations where the representation had been made not as to an existing matter of fact but as an assurance with respect to a future course of conduct.

A third type of estoppel, estoppel by acquiescence, has been developed to fill the gap in situations where there has been no overt representation either by words or conduct as to an existing fact or as to a future course of action, but there has been a failure to act on the part of a representor in situations where there was a duty to act. A succinct description of estoppel by acquiescence is given by Spencer Bower and Turner as follows: ${ }^{34}$

Where $A$ has a right or title which $B$ is in fact infringing under a mistaken belief that his acts are not infringements at all, and $A$ is aware of his own title or right, and is also aware of B's invasion of that title or right, and of his erroneous belief that he is not encroaching thereon, but is lawfully exercising rights of his own, and yet, with that knowledge, A so conducts himself, or so abstains from objection, protest, warning or action, as to foster and maintain the delusion under which he knows that $B$ is labouring, and induces $B$ to act to his prejudice on the faith of the acknowledgement to be implied from such conduct or inaction, $A$ is not permitted afterwards to assert his own rights against $B$, or contest $B$ 's rights against himself.

Estoppel by acquiescence differs from other forms of estoppel, not only because it is based on silence or inaction but also because it requires that the party to be bound must possess a high degree of actual knowledge and because it is generally understood that estoppel by acquiescence can found a cause of action. ${ }^{35}$

32. [1956] 1 All E.R. 256 which was based, in part, upon Hughes v. Metropolitan Ry. Co. (1877) 2 App. Cas. 439; Birmingham \& District Land Co. v. London \& North Western Ry. Co. (1888) 40 Ch. D. 268, and which was followed and limited by Combe v. Combe [1951] 2 K.B. 215.

33. 16 Halsbury's Laws (4th) para. 1514 at 1017.

34. Supran. 31 at 283-284.

35. Id. at 283-284. 
The fourth type of estoppel which has been used in oil and gas situations is estoppel by deed which frequently comes into existence when the parties have acknowledged a specific state of affairs by executing a written document. Although it seems at first glance to be a part of the area of contract, it falls outside the law of contract because there is no express agreement on the point in issue between the parties, although the document itself leads to the obvious conclusion that the parties have indeed consented to act upon an assumed state of affairs. Once they have done this, it is not possible thereafter to assert the contrary.

In a series of cases, mostly, but not all Western Canadian cases at the trial or Court of Appeal level, courts in the early sixties seemed to be pointing in the direction of allowing estoppel to be used as a means of reviving an otherwise terminated lease. It is not proposed in this article to discuss these earlier decisions in view of the fact that other authors have carefully reviewed them ${ }^{36}$ and in view of the fact that subsequent decisions by the Supreme Court of Canada have narrowed considerably the ambit within which estoppel may be used in freehold oil and gas fact situations.

\section{CANADIAN SUPERIOR v. PADDON-HUGHES AND HAMBLY}

The first Supreme Court decision to deal specifically with the question of estoppel in an oil and gas freehold lease situation was Canadian Superior Oil Ltd. v. Paddon-Hughes Development Co. Ltd. and Ralph Hambly. ${ }^{37}$ The lease in question was found by all Courts to have terminated at the end of the extended primary term, that is upon the completion of drilling, because of the lack of production, either actual or constructive, as of that date. This was on the basis of Canadian Superior Oil of California, Ltd. v. Kanstrup et al. ${ }^{38}$ The second issue was whether certain actions on the part of the lessor would be sufficient to raise a defence of estoppel by representation or by acquiescence, sufficient to revive the lease. The actions on the part of the lessor, which it was argued established an estoppel, may be summarized as follows:

(a) Shut-in royalties had been paid and received for a number of years by a trust company pursuant to a royalty trust agreement that had been previously entered into by the lessor. It was the duty of the trust company to receive and distribute these payments to royalty trust certificate holders and during the relevant period when the estoppel was allegedly raised only two distributions had been made. The lessor had returned his proportionate share of the second distribution.

(b) Pursuant to a surface lease, a number of surface rental payments were paid to the lessor by the lessee.

(c) The lessee had frequently obtained consent from the lessor to conduct various operations with respect to the well.

36. Ballem, "The Continuing Adventures of the Oil and Gas Lease", supra n. 29 at 435 , Ballem, supran. 1 at 283.

37. Supra n. 29.

38. [1965] S.C.R. 92. 
(d) At one point, the lessor saw that a well pressure gauge indicated that gas pressure was dangerously high and had advised the lessee to that effect.

(e) The lessor, as part of the collateral security with respect to a mortgage, had executed an agreement which assigned to the mortgagee "all bonuses, rentals, delay rentals and other considerations and benefits" which were payable pursuant to certain leases and surface leases. One of these leases was the subject of the action.

Neither the Trial Court nor the Court of Appeal found that these actions were sufficient to establish a case based upon estoppel by representation.

Martland J., writing the judgment for the Supreme Court of Canada, expressed serious doubt as to whether estoppel could ever be raised where the representations that formed the basis of the estoppel occurred subsequent to the termination of the lease. His Lordship noted that, whether based upon estoppel by representation or promissory estoppel, the argument would not be successful unless the representations had occurred prior to the termination of the lease. He also noted that both estoppels assumed "the existance of a legal relationship between the parties when the representation is made".${ }^{39}$ Martland $\mathrm{J}$. also observed that there was no evidence to support estoppel by acquiescence, as there was no evidence that the lessor was aware that the lease had terminated when he performed any of the actions which were argued to be the basis of the estoppel.

In reviewing the case, two observations come to mind. First, it is unlikely that estoppel by representation or promissory estoppel will succeed in an oil and gas lease situation, simply because in the normal course, the lessor, being unaware of the termination of the lease, will accept payment of delay rental or shut-in royalty payments with the result that the lease will have terminated prior to the actions on the part of the lessor which might possibly raise the estoppel. There will be few situations in which the lessor, prior to the termination of the lease, through actions or words, will represent to the lessee that, notwithstanding the failure to pay shut-in royalty or delay rental in accordance with the terms of the lease, he will treat the lease as still being valid. Secondly, it is important to note that Martland J. expressly reserves a final comment on the question of acquiescence and contemplates that, in the appropriate fact situation, acquiescence could create an estoppel, indeed could found a cause of action based upon estoppel, notwithstanding that the lease had terminated prior to the silence or inaction on the part of the lessor which arguably would found the estoppel. More will be said about the question of acquiescence in our discussion of the Voyager case, infra.

\section{SOHIO PETROLEUM v. WEYBURN}

An equally significant decision of the Supreme Court of Canada is Sohio Petroleum Company v. Weyburn Security Company Limited.40

39. Supra n. 29 at 938.

40. Supran. 27. 
Once again, it was held that the lease had terminated because there had been no production within the ten-year primary term of the lease. The major issue to be decided was whether certain actions on the part of the lessor amounted to representations that, notwithstanding its technical termination, the lease was to be considered as binding and enforceable, thus establishing the defence of estoppel by representation. The words and the conduct on the part of the lessor which were relied on were much more substantive than they had been in the earlier Hambly decision and were as follows:

(a) Weyburn had required Sohio to drill an offset well in accordance with the terms of the lease and this well was drilled.

(b) At the request of Weyburn, Sohio paid seven-eighths of the mineral taxes imposed on the land subject to the lease, all as required by the lease.

(c) Sohio had paid and Weyburn had accepted royalties based on production from the leased lands. Weyburn permitted Sohio to enter a pooling agreement including the leased lands which, under the terms of the lease, Sohio could have done without Weyburn's consent.

It is important to note that all of these actions had occurred subsequent to the technical termination of the lease. Both the Saskatchewan Court of Appeal and the Supreme Court of Canada held that neither estoppel by representation, nor promissory estoppel, nor estoppel by acquiescence had been established and that the lease had terminated. ${ }^{41}$ Martland J., emphasized once again that estoppel by representation or promissory estoppel could not be established where the acts alleged to give rise to the estoppel occurred after the lease had terminated. In addition, it was clear on the facts in this particular case that none of the actions by Sohio had been taken based upon any representations, if they were indeed representations, by Weyburn, but were taken simply because Sohio mistakenly believed that the lease had not terminated. The Court relied upon a judgment of Egbert J. in Calvan Consolidated Oil \& Gas Co. v. Manning which stated in part: ${ }^{42}$

There was no representation made or conduct amounting to representation done by the plaintiff with the intention of inducing any conduct on the part of the defendant. Here both parties acted under a mistake - whether a mistake of law or a mistake of fact is of no consequence - and there is no question of either party having made any representation to the other. Whatever the defendant did - and his consequent action is an essential ingredient of estoppel - he did because of his own mistake and not by reason of any representation of the plaintiff.

Martland J. also found that there were no facts that would support a finding of fraud on the part of Weyburn sufficient to establish estoppel by acquiescence. Since Weyburn was not aware of its true legal position, it could not be precluded from exercising its rights. ${ }^{43}$

The fact that both Courts were clearly of the view that Sohio's actions were not taken because of any alleged representation by Weyburn, but

41. (1969) 69 W.W.R. 680 (Sask. C.A.), [1971] S.C.R. 81.

42. (1957) 22 W.W.R. 433, at 453 (Alta. S.C.T.D.).

43. Supran. 41 at 81-82. 
were taken independently because Sohio mistakenly believed that the lease was still in existence, demonstrates once again how difficult it would be for a lessee to set up a defence based upon estoppel by representation or promissory estoppel. As Rowland J. Harrison pointed out in commenting on the case, ${ }^{44}$ it was clear on the facts that Sohio did what it did based upon its own conclusions regarding the continued validity of the lease. The primary term expired on October 27th, 1959, but it was not until January, 1960 that any royalties were paid and accepted and a further two months before the lessor made a demand to drill an of fset well. For at least two months, considerable work was performed by Sohio and expenditures made (i.e. the well was completed and produced) before anything happened on the part of the lessor that could be alleged to be a representation by the lessor. Harrison notes: ${ }^{45}$

\begin{abstract}
In other words, more than five months elapsed during which Sohio can have proceeded on no other basis than that it had formed the mistaken belief that the lease was still in force... . The conclusion which necessarily follows is that all the actions allegedly undertaken by Sohio on the basis of "representations" by Weyburn were undertaken in fact because it believed it was bound to do so under the lease. The alleged representations may well have confirmed Sohio's belief that the lease was still in force but they cannot have formed that belief in any causal sense because the belief must have existed before any representations, arguably sufficient to constitute any estoppel, were made.
\end{abstract}

It is important to note that in both the Hambly and Weyburn decisions, the plea for estoppel by acquiescence was referred to but, except at the Court of Appeal level in Weyburn, was not dealt with extensively. It was clear that all judges felt that the lessors in both situations were not aware of the fact that the lease had terminated in the sense that would be required to establish estoppel by acquiescence. Because of the fundamental requirement that the party to be estopped must be aware of the true factual situation, no one would have viewed estoppel by acquiescence as a serious ground upon which any lessee might successfully plead estoppel. In most fact situations, the lessor would be genuinely ignorant of the fact that the lease had expired and the facts which might conceivably have given him this knowledge would, in most instances, be more generally available to the lessee than to the lessor.

\title{
E. VOYAGER PETROLEUMS v. VANGUARD PETROLEUMS
}

The decisions of the Alberta Court of Queen's Bench and the Alberta Court of Appeal in Voyager Petroleums Ltd. v. Vanguard Petroleums $L t d .{ }^{46}$ a case in which the plea of estoppel by acquiescence was successfully raised to revive an otherwise terminated freehold lease, require very close scrutiny to determine whether estoppel by acquiescence will become a more powerful weapon in the hands of a lessee faced with a terminated lease than was otherwise thought to be the case.

The lease in question was granted by a predecessor to Vanguard on May 27th, 1966. The lease was for a ten-year term. The minerals were subject to a Gross Royalty Trust Agreement pursuant to which a 121/2 per

\footnotetext{
44. Harrison, "Selected Cases, Legislation and Developments in Oil and Gas Law", supra $\mathbf{n}$. 29 at 391.

45. Id. at 401 .

46. [1982] 2 W.W.R. 36 (Alta. Q.B.), supran. 30 (Alta. C.A.).
} 
cent gross royalty had been assigned to Canada Permanent Trust Company. Therefore, Vanguard was interested in the leased substances both in its capacity as a registered owner of the minerals and the lessor under the lease, and as the holder of a majority of the trust units under the Trust Agreement. The president and managing director of Vanguard was an experienced businessman as well as a practicing barrister and solicitor. In 1972, Voyager, through Western Land Services Co. Ltd., prepared a Unit Agreement incorporating the lands subject to the lease. Canada Permanent executed the Unit Agreement but Vanguard did not. It was agreed that Vanguard was required to sign the Unit Agreement in two capacities, as the owner of the minerals and the lessor under the lease, and as the holder of gross royalty units. Voyager made its last payment of delay rentals in April of 1972, which would have maintained the lease in good standing until May 27th, 1973. No delay rentals were paid after that date, based upon Voyager's understanding that the Unit Agreement maintained the lease. In August 1976, Voyager drilled a successful natural gas well just outside the lands covered by the lease and attempted to pool the lands on which the natural gas well had been drilled with the lands contained in the lease. Vanguard took the position that, since it had not signed the Unit Agreement as the owner of mineral rights, the lease had terminated on May 27th, 1973. Voyager commenced an action to establish the validity of the lease on the basis that Canada Permanent had acted in signing the Unit Agreement as an agent of Vanguard and that Vanguard should be estopped from denying the validity of the Unit Agreement.

It is also important to note certain facts which the Court relied upon in reaching its conclusions. By letter dated September 21st, 1972, Western Land forwarded to Vanguard two copies of the Unit Agreement requesting that both be signed and returned. Vanguard did not sign, but sent both copies to Canada Permanent, the trustee under the Trust Agreement, with a letter dated October 3rd, 1972 which authorized Canada Permanent to sign the Unit Agreement pursuant to Clause 16 of the Royalty Trust Agreement. Voyager was not aware of the contents of the October 3rd, 1972 letter. Canada Permanent signed both copies of the Unit Agreement and sent them to Western Land on October 25th, 1972, indicating that the agreements had been signed by Canada Permanent as requested by Vanguard. Western Land then sent the two executed copies of the Unit Agreement to Voyager.

The Trial Judge found that, because of the limiting words contained in Vanguard's October 3rd, 1972 letter, it did not constitute "an actual or express authorization or appointment of or to Canada Permanent to sign the unit agreement for Vanguard in any capacity other than as a holder of gross royalties". ${ }^{47}$ The Court of Appeal did not comment on this aspect of the case.

With respect to estoppel, Stratton J. in the trial judgment preferred to approach the question from the narrower perspective of whether "Vanguard, by its action or inaction, is estopped from denying that Canada Permanent acted as agent for it in signing the unit agreement

47. Id. (Alta. Q.B.) at 48. 
without qualification and therefore bound Voyager as its principal, in both capacities, to the terms of that agreement", rather than looking at it in a broader context of whether Vanguard was estopped from denying that it was bound by the Unit Agreement ${ }^{48}$ The Trial Judge also concluded that the actions of Vanguard did not constitute ". . . the type of positive or active representation of fact necessary to ground estoppel by representation". ${ }^{49}$

The question of estoppel by acquiescence was analyzed extensively both by the Trial Court and by the Court of Appeal and is, therefore, of particular interest. Both Courts referred to the classic statement of the constituent elements of estoppel by acquiescence contained in the judgment of Fry L. J. in Willmott v. Barber: ${ }^{50}$

\begin{abstract}
It has been said that the acquiescence which will deprive a man of his legal rights must amount to fraud, and in my view that is an abbreviated statement of a very true proposition. A man is not to be deprived of his legal rights unless he has acted in such a way as would make it fraudulent for him to set up those rights. What, then, are the elements or requisites necessary to constitute fraud of that description? In the first place the plaintiff must have made a mistake as to his legal rights. Secondly, the plaintiff must have expended some money or must have done some act (not necessarily upon the defendant's land) on the faith of his mistaken belief. Thirdly, the defendant, the possessor of the legal right, must know of the existence of his own right which is inconsistent with the right claimed by the plaintiff. If he does not know of it he is in the same position as the plaintiff, and the doctrine of acquiescence is founded upon conduct with a knowledge of your legal rights. Fourthly, the defendant, the possessor of the legal right, must know of the plaintiff's mistaken belief of his rights. If he does not, there is nothing which calls upon him to assert his own rights. Lastly, the defendant, the possessor of the legal right, must have encouraged the plaintiff in his expenditure of money or in the other acts which he has done, either directly or by abstaining from asserting his legal right. Where all these elements exist, there is fraud of such a nature as will entitle the Court to restrain the possessor of the legal right from exercising it, but, in my judgment, nothing short of this will do.
\end{abstract}

These criteria have been referred to as the five probanda in Willmott $\mathrm{v}$. Barber.

The third probanda of Willmott v. Barber is obviously the most difficult one to fulfill, that is, to establish that the possessor of the legal right has knowledge of the existence of his own right which is inconsistent with the right claimed by the other party. Stratton J. reviewed modern decisions dealing with the third probanda to decide whether actual knowledge of the right is required, thus constituting actual fraud, or whether something less than actual knowledge of the right would be sufficient, i.e. knowledge of the facts which would support the existence of the right. A leading English decision in this area is Holder v. Holder, ${ }^{51}$ which used estoppel by acquiescence to prevent one beneficiary of an estate from setting aside the sale of certain farms to one of the executors of the estate. The executor had renounced his executorship prior to the sale, but his renunciation was subsequently found to be invalid because he had participated in some acts of administration of the estate. The beneficiary in question attempted to have the sale overturned on the

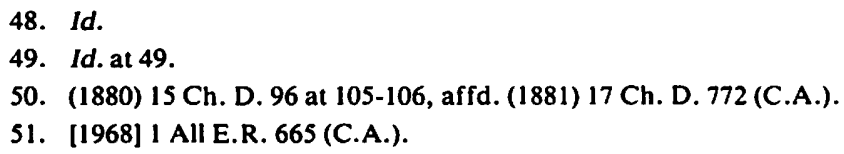


ground that the executor was a trustee of the property he had purchased. The Court held that although the beneficiary did not know until later that he had the right to overturn the sale by reason of the executor's renunciation being found to be invalid, he did have full knowledge of the sale, had allowed the sale to go through without attempting to stop it, had received money on account and, therefore, was held to have acquiesced in the sale.

Harman L. J., in finding on behalf of the executor that estoppel by acquiescence had been established against the beneficiary, quoted a midnineteenth century decision to the effect that when the facts are known from which a right arises, the right is presumed to be known and concluded: ${ }^{22}$

There is, therefore, no hard and fast rule that ignorance of a legal right is a bar, but the whole of the circumstances must be looked at to see whether it is just that the complaining beneficiary should succeed against the trustee.

Using Holder v. Holder as an example of a more modern and less technical approach to the question of estoppel by acquiescence ${ }^{53}$ (i.e. viewing estoppel on the basis of ordinary common law principles of construction and of what would be considered to be reasonable without fine distinctions or technicalities), Stratton J. concluded that when the term "fraud" is used in the context of the five probanda of Willmott v. Barber, it is not used in the sense of "wilful and deliberate dishonesty but rather in the more restricted sense accepted by the rules of equity and usually defined as "equitable or constructive fraud" ". ${ }^{54}$ Having concluded that this was the meaning of fraud within the context of Willmott $\mathrm{v}$. Barber, His Lordship then had little difficulty in determining that Vanguard did know of the existence of its own right which was inconsistent with the right claimed by Voyager. Ultimately it was held that Voyager had established all five of the probanda and Vanguard was estopped from denying that Canada Permanent was authorized to sign the Unit Agreement on behalf of Vanguard both in its capacity as a holder of a portion of the units under the gross royalty trust and as the lessor and owner of the minerals. The Court of Appeal upheld this conclusion in every respect.

A number of observations can usefully be made about the decisions in Vanguard v. Voyager. First of all, both the Trial Judge and the Court of Appeal were of the view that for Voyager to succeed in establishing estoppel by acquiescence, it was necessary to prove that all of the actions which formed the basis of the estoppel had occurred prior to the termination of the lease. This was the basis for distinguishing the adverse decisions of the Supreme Court of Canada in Sohio v. Weyburn and Canadian Superior v. Hambly. This conclusion does not appear to be correct. In fact, Martland J. in both Supreme Court decisions seemed to assume that estoppel by acquiescence could revive an otherwise terminated lease. Thus, if the five probanda of Willmott v. Barber can be satisfied, estoppel by acquiescence would revive an otherwise terminated

52. Id. at 673 .

53. Supra n. 47 at 52.

54. Id. at 54 . 
lease even though the actions or non-actions giving rise to the estoppel occurred subsequent to the termination of the lease.

A second observation is that one can view Voyager $v$. Vanguard as a decision based upon very specific facts which perhaps justified the approach which the Court of Appeal took to the question of estoppel. The Courts accepted that Vanguard was aware of facts which supported its right to assert that the Unit Agreement had never been properly executed, facts which were not within the knowledge of Voyager. In particular, Vanguard forwarded the two copies of the Unit Agreement to Canada Permanent with the express authorization to execute the Unit Agreements in accordance with the Royalty Trust Agreement. Authority was not given to sign on behalf of Vanguard as the lessor of the minerals. Vanguard was clearly aware of this situation, since it wrote the letter. Voyager was not aware of this limitation of authority, although it knew the Unit Agreements had been forwarded to Canada Permanent. When Canada Permanent returned the signed Unit Agreements to Western Land (the agent for Voyager), it was not unreasonable that Voyager should assume that the Unit Agreement had been properly signed by Vanguard in both its capacities (through the signature of Canada Permanent). There were no other facts at its disposal to displace this assumption and Vanguard did not take exception to this nor did it apprise Voyager of the contrary facts. The broad approach with respect to the third probanda in Willmott v. Barber, applied in Holder v. Holder, was perhaps also appropriately applied in Vanguard v. Voyager, in that it would have been arguably unjust to allow Vanguard to adopt the position that the Unit Agreement had not been properly executed in view of its specific knowledge to the contrary and in view of its subsequent silence, just as it would have been unjust to allow the beneficiary to attack the sale to the executor in view of the knowledge of facts which the beneficiary had with respect to the sale and in view of his failure to raise any objections to the sale.

However, it is extremely unlikely that, in a normal freehold oil and gas situation involving failure to pay delay rental or shut-in royalty payments, the approach taken by the Court of Appeal in Vanguard v. Voyager would ever be appropriate. The decision in Vanguard v. Voyager has made it easier for a lessee attempting to revive an otherwise terminated lease to assert that the lessor had knowledge of his true legal position, insofar as it would not be required to prove actual knowledge of more than the facts that gave rise to the legal right. Unfortunately, it is almost impossible to imagine a situation in which the lessor would be aware of facts of which the lessee would not already be aware. Indeed, drilling information and other information relating to the status of the well and the date of completion would usually be more within the knowledge of the lessee than the lessor. Spencer Bower \& Turner note, with respect to estoppel by acquiescence that: ${ }^{55}$

... there is no estoppel where the parties are equally ignorant of their specific rights, any more than there is when they are equally aware of them.

55. Supran. 31 at 271 . 
Therefore, in most situations, even if the lessor was a highly sophisticated businessman with access to reputable legal advice on oil and gas matters, it is unlikely that the lessor would possess as much knowledge of the facts that might give rise to an estoppel as would the lessee. Thus, although estoppel by acquiescence in theory could provide the basis for reviving an otherwise terminated oil and gas lease, its application will be restricted to unusual and specific situations such as arose in Vanguard v. Voyager. Generally speaking, failure to comply with the strict terms of a lease in situations involving shut-in royalty or delay rental will lead to the automatic termination of the lease, and estoppel will not succeed in reviving it.

\section{SHUT-IN ROYALTIES}

\section{A. INTRODUCTION}

During the 1980 - 1985 period, the Canadian oil and gas industry has been faced with a difficult marketing situation with respect to natural gas. As the marginal growth in domestic sales has been off-set by the reduction in export sales to the United States, the overall demand for natural gas remains close to its 1980 level. The lack of demand for natural gas has forced the industry to orient its exploration and development programs to oil rather than gas. Nevertheless, a significant number of gas wells have been drilled during this time period. In 1984 alone, over 1800 gas wells were completed in Canada. ${ }^{56}$ With little hope of securing a market for the gas from these wells, many of them have had to be shutin. A large number of these wells were completed in shallow gas zones which are located in the central and south-eastern regions of Alberta. This shallow gas prone area coincides with the region which has a significant proportion of freehold ownership of the mines and minerals.

The potential pitfalls to an oil and gas company as the lessee of a freehold lease are numerous. There is also a growing awareness and sophistication among lessors with respect to their rights under these documents, with an increased willingness to take advantage of any mistake by the original lessee. When these factors are coupled with the large number of shut-in wells on freehold lands, a review of one of the fundamental terms of the freehold lease, the shut-in royalty clause, seems in order.

The possible problems and issues associated with the operation of the shut-in clause are numerous and no attempt will be made in this paper to address them all. Two issues will be addressed: first, when is a shut-in royalty payment required to be made in order to preserve the lease, and secondly, what conditions must be present before a shut-in payment can be validly tendered. Both issues can be crucial to the continuation of the freehold lease and were issues involved in the recent Alberta case of Kissinger Petroleums Ltd. v. Keith McLean Oil Properties Ltd. and Falcon Resources Ltd. ${ }^{57}$

56. Oilweek, 4 February 1985 at 22.

57. [1984] 5 W.W.R. 673 (Alta. C.A.), 26 Alta. L.R. (2d) 378 (Q.B.). Leave to appeal to S.C.C. denied 14 November 1984. 
The Alberta Court of Appeal and the Supreme Court of Canada have been called upon to deal with issues concerning the shut-in clause in five major cases. ${ }^{58}$ Given the somewhat limited Canadian jurisprudence on the overall matter of the interpretation of the freehold lease, the fact that five cases have dealt with the shut-in clause is significant. However, this appears insignificant when contrasted with the extensive United States jurisprudence on the shut-in clause. Since case law from the various oil and gas producing states in the United States can be useful in trying to interpret the shut-in clause correctly, this paper will contain several references to American authorities and commentators. The appropriateness of using American authorities in oil and gas matters in Canada has been commented on by Mr. Justice Morrow in Telstar Resources Ltd. v. Coseka Resources Limited as follows: ${ }^{59}$

Canadian Courts have consistently accepted help in the use and interpretation of terms in the oil and gas business from the courts in the United States because of their much wider experience in problems arising from the development of oil and gas fields and the production of these substances.

Just as the freehold lease does not have a "standard" form, there is no such thing as a "standard" shut-in clause. The shut-in clause occurs in many variations and the exact words used in the lease must be examined carefully. The role of the courts is to interpret the words which have been used by the parties and traditionally Canadian courts have taken a very strict and technical approach to the interpretation of the terms of the freehold lease. Subtle differences in wording have a profound effect on the manner in which shut-in payments must be tendered. While no "standard" form of the shut-in clause exists, it will be helpful for the purposes of this paper, to refer to some common examples of shut-in royalty clauses appearing in Canadian leases:

\section{Example 1:}

If at the expiration of any year during the primary term or any extended term of this Lease and Grant there be a well or wells upon the said lands, or upon lands with which the said lands and leased substances or any part or parts thereof have been pooled or unitized, or upon lands adjacent to the said lands and included in a spacing unit wherein the said lands or any portion thereof is comprised, from which leased substances are not produced as a result of a lack of or an intermittent or uneconomical or unprofitable market or any cause whatsoever beyond the Lessee's reasonable control, the Lessee may, on or before such anniversary date pay to the Lessor in the same manner provided for the payment of delay rental hereunder, as royalty, an amount equal to the annual delay rental payable hereunder, and if such sum is so paid, such well or wells shall be deemed to be a producing well or wells on the said lands under all the provisions of this Lease and Grant for the following Twelve (12) month period. By like payment made in a like manner such well or wells shall be deemed to be producing for like periods successively.

Example 2:

If during the primary term or at the expiration of the primary term or at any time or times thereafter all wells on the said lands, or on pooled lands or unitized lands, are, either before or after production of leased substances has been obtained therefrom,

58. Canadian Superior Oil of California, Ltd. v. Kanstrup et al, supra n. 38; Canadian Superior Oil Ltd. v. The Paddon-Hughes Development Co. Ltd. and Ralph Hambly, supra n. 29; Canadian Superior Oil Ltd. v. Murdoch (1969) 70 W.W.R. 768 (S.C.C.); 68 W.W.R. 390 (Alta. C.A.), 64 W.W.R. 473 (Q.B.); Shell Oil Co. v. Gunderson [1960] S.C.R. 424; Kissinger Petroleum Ltd. v. Keith McLean Oil Properties Ltd. and Falcon Resources Ltd., supra n. 57.

59. (1980) 12 Alta. L. R. (2d) 187 (C.A.) at 190. 
shut-in, suspended, capped or otherwise are not being produced, as the result of a lack of or an intermittent market or any cause whatsoever beyond the Lessee's reasonable control, the Lessee may pay or tender to the Lessor within sixty $(60)$ days after the date of such wells being shut-in, suspended, capped or otherwise not being produced, a royalty payment equal to the amount of the delay rental provided for in this lease, to cover the period from the date such wells are shut-in, suspended, capped or otherwise not being produced to the next anniversary date of this lease. Further, the Lessee may pay or tender to the Lessor within sixty (60) days after the said next anniversary date and each successive anniversary date thereafter of this lease a royalty payment equal to the amount of the delay rental provided for in this lease, each said payment to cover the period from the anniversary date within sixty $(60)$ days of which said payment was paid or tendered to the next succeeding anniversary date. As often as such payments or tenders are made it shall be considered under all provisions of this lease that leased substances are being produced from the said lands during the entire period for which such royalty is paid or tendered.

Example 3:

If all wells on the said lands or the pooled lands are shut-in, suspended or otherwise not produced during any year ending on an anniversary date as the result of a lack of or an intermittent market, or any cause whatsoever beyond the Lessee's reasonable control, the Lessee shall pay to the Lessor at the expiration of each said year a sum equal to the delay rental hereinbefore set forth, and each such well shall be deemed to be a producing well hereunder.

Example 4:

If at the expiration of any year during the primary term or any extended term of this Lease there is no producing well on the said lands or the pooled lands but there is a well on the said lands or the pooled lands which is designated a gas well by or pursuant to any applicable statute or regulation, or by the board, governmental authority or agency having jurisdiction in that regard, and from which no leased substances are being produced as a result of the lack of an economical or profitable market, such well shall be deemed to be a producing well on the said lands under all the provisions of this Lease and the Lessee shall, on or before such anniversary date, pay to the Lessor in the same manner provided for the payment of the delay rental hereunder, as royalty, an amount equivalent to the delay rental. Like payments shall be made in a like manner on each successive anniversary date during the period that such well is deemed by virtue of this Clause to be a producing well on the said lands.

\section{B. EVOLUTION OF THE SHUT-IN ROYALTY CLAUSE}

The shut-in royalty clause is directly linked with the habendum provision of the lease. The habendum clause defines the duration or term of the lease and contains a primary term and a secondary term. The primary term is the fixed-year portion (commonly five to ten years), while the secondary term arises from wording "and so long thereafter as the leased substances or any of them are produced from the said lands".

In the absence of a shut-in clause, in order to establish "production" for the purposes of the habendum, there had to be actual production. It was not sufficient simply to have a well which was capable of production. ${ }^{60}$ Clearly, it was not equitable for a lessee to lose its lease in this situation. The lessee had drilled and completed a productive well and usually the reason why the well was not on production at the end of the primary term was because of matters beyond its direct control. The shutin royalty clause was developed to avoid this inequity and to provide a method by which the lessee could maintain the lease between the end of the primary term and the time when actual production commenced.

The first shut-in clauses were limited to gas wells, because shut-in gas wells were the most common occurrence. An oil well can usually be plac-

60. Stanolind Oil \& Gas Co. v. Barnhill 107 S.W. (2d) 746 (Tex Civ. App. 1937). 
ed on production soon after completion, but the operator of a gas well does not have the same degree of control over the marketing of gas. Often, several gas wells must be drilled to prove up sufficient reserves to obtain a contract to sell the gas. While oil production can be trucked to a refinery, gas production requires the installation of expensive pipeline facilities. The operator of an oil well can always produce the well to tanks on the wellsite and store the oil, an option which is not available for gas. For these reasons, early shut-in clauses only referred to "gas wells" rather than using the more general term "wells". To obtain greater protection for the lessee, the reference in most current shut-in clauses is to "wells", although some forms (see Example 4) still are limited to "gas wells". A clause which is limited to "gas wells" can cause problems where wells produce solution gas or a high volume of condensate.

\section{WHEN IS A SHUT-IN PAYMENT REQUIRED TO BE MADE TO PRESERVE THE LEASE?}

A distinction must be made between the issue of when a shut-in payment is required to be made in order to preserve the lease and the more general issue of when a shut-in payment is required to be made pursuant to the terms of the lease. The general issue can be determined from a simple reading of the shut-in clause to determine whether the obligation to tender a shut-in payment is "optional" (in that the shut-in clause uses the word "may", as in Examples 1 and 2) or "mandatory" (in that the shutin clause uses the word "shall", as in Examples 3 and 4). However, the issue of greater concern is when is it essential to make a shut-in payment to maintain the lease. The answer requires a detailed examination of the shut-in clause. This examination will show that, even if a shut-in clause is of the "optional" type, there are certain circumstances in which a payment must be made, and that, although a shut-in clause may be of the "mandatory" type, a missed payment does not necessarily mean that the lease is terminated.

Under the "optional" shut-in clause, it is the actual payment of the shut-in royalty which deems the shut-in well to be a producing well under all the provisions of the lease. The wording used is similar to that found in Example 1: "and if such sum is so paid, such well or wells shall be deemed to be a producing well". Several "mandatory" shut-in clauses also state that it is the payment of the shut-in royalty which gives rise to the deeming of production. However, most of the "mandatory" clauses used in new leases today are similar to Example 3. This clause, while providing for the payment, does not link the making of the payment directly with the deeming of production. The words "and each such well shall be deemed to be a producing well hereunder" would probably be interpreted to mean that the lease would be extended by the mere presence of a shutin well, regardless of whether a shut-in payment was made. While there is nothing wrong with this result, the question is whether this was what the parties, or at least the lessor, intended. The drafting in Example 3 has somewhat camouflaged the result by simply tacking the "deeming" phrase on to the end of the shut-in clause which is primarily concerned with shut-in payments. A more appropriate place to include this provision would be in the habendum itself which could be drafted to provide a 
"primary term of 5 years and so long thereafter as leased substances are being produced or so long thereafter as there is a shut-in well on the lands". Example 4 is an improvement on Example 3, because it clearly sets out that it is the presence of the shut-in well alone which gives rise to the deeming of production.

The amount of the shut-in royalty payment is usually equivalent to the annual delay rental, typically one dollar per acre. Thus, for the normal gas well spacing unit, the total payment is 640 dollars per year, a figure which seems to have remained fairly constant over the years. Earlier leases seem to be more oriented to the "optional" shut-in clause, while current freehold leases predominantly contain the "mandatory" shut-in clause. Perhaps lessees have come to realize that the automatic annual payment of 640 dollars is cheap insurance against the potential risk of losing a lease from the incorrect interpretation of an "optional" shut-in clause. The "mandatory" clause may also be favoured because it makes the payment of a shut-in royalty an obligation and thereby permits the argument that failure to pay a mandatory shut-in payment triggers the default clause in the lease. Under the default clause, the lessor is obliged to give notice of non-payment to the lessee, who then has a specified period of time (usually ninety days) in which to correct the default by tendering payment. If payment is made (and it is unlikely that any oil company would ignore a default notice), the lease will continue. The default clause cannot be relied upon to excuse the non-payment of an "optional" shut-in royalty, ${ }^{61}$ and has been found to be inapplicable with respect to a "mandatory" shut-in clause which stated that it was the payment itself which gave rise to the deeming of production. ${ }^{62}$

The general rule for determining when a shut-in payment is necessary is that it must be made when the lease is not being continued by any other provision. The modern-day "mandatory" clauses appear to contain the phrase continuing the lease in the shut-in clause itself and there would be no requirement to make any payments to hold the lease. However, for the "optional" clauses and for older forms of the "mandatory" type, the relationship between the shut-in clause and the habendum, including its provisos, must be analyzed carefully. Since different results occur at different times in the term of the lease, each stage will be examined separately.

\section{Shut-in Payments During The Primary Term}

Although the matter has not been addressed by the Canadian courts, United States cases and commentators agree that it is generally not necessary to make a shut-in well payment during the primary term to maintain the lease to the end of the primary term. The leading case is Sohio Petroleum Co. v. V.S. \& P.R.R., ${ }^{63}$ where the lessor brought an action for the cancellation of a lease during the fourth year of the primary term. A gas well had been completed and shut-in during the first year of the primary term and there had been no subsequent tender of any delay

61. Canadian Superior Oil of California Ltd. v. Kanstrup et al, supra n. 38.

62. Canadian Superior Oil Lid. v. Murdoch 64 W.W.R. 473 (Alta. Q.B.) at 480.

63. 62 So. (2d) 615 (La. S.C. 1952). 
rentals or shut-in payments under an "optional" shut-in clause. The Court determined that the habendum clause itself provided that the lease should continue for a primary term of ten years and that production was important only after the expiration of this period. Thus, the Court felt that unless some terminating provision was identified, the lease remained in effect during the entire primary term. In its search for provisions which might terminate the lease, the Court examined the various provisos to the habendum. The first proviso concerning the obligation to drill a well or pay delay rentals did not apply, because a well had been drilled and the lessee had thereby been released from any obligation to make delay rental payments. The second proviso contained a "dry hole" clause, by which the lessee was obligated to drill a further well or resume delay rentals if the initial well was a dry hole. The Court held that a shutin well was not a dry hole, since the well was capable of production. The second proviso also contained a "cessation of production" clause, by which the lessee was obligated to drill a further well or resume delay rental payments if production of the leased substances had ceased. This portion of the second proviso was held to be inapplicable, because as production had never commenced there could be no "cessation".

Thus, in most circumstances, a shut-in well payment will not be required to be made during the primary term of the lease in order to maintain its validity. Once again, however, the annual payment of 640 dollars to maintain a productive well is cheap insurance against any arguments that might be raised to the contrary and, obviously, each lease will require examination to ensure that its provisions corresponded with the Sohio lease.

\section{Shut-in Payments At The End Of The Primary Term}

Most shut-in clauses provide that a payment can be made at the expiration of any year during the primary term or any extended term of the lease. If the Sohio case is accepted as good law in Canada, the reference to "any year during the primary term" is unnecessary for the early years of the primary term. However, payment at (or immediately before) the expiration of the final year of the primary term is necessary, because "production" is required to extend the lease beyond its primary term, and payment of the shut-in payment deems production to be occurring. Since the primary term expires at midnight on the date immediately prior to the date of the lease, ${ }^{64}$ there must be a provision which allows payment to be tendered while the lease is still in force.

This issue has been raised in two Canadian cases. In Canadian Superior Oil of California Ltd. v. Kanstrup et al, ${ }^{65}$ the lease was dated July 2, 1948 and had a ten-year primary term and an "optional" shut-in royalty clause. A well was drilling in June 1958 and a shut-in payment tendered July 9, 1958. The Court held that the lease expired at the end of the primary term because the shut-in payment was tendered too late. The same result occurred in Canadian Superior Oil Ltd. v. Murdoch, ${ }^{66}$ where

64. Canadian Fina Oil Limited v. Paschke (1957) 21 W.W.R. (N.S.) 260 (Alta. S.C.A.D.).

65. Supra n. 38.

66. Supran. 58. 
the well was completed just two days prior to the expiry of the primary term but the payment of the shut-in payment was not made until some three weeks later. These Canadian decisions are consistent with the American authorities on this matter. ${ }^{67}$

Although the payment must be made in advance of the expiry date, it would not seem to be advisable to make the payment too far in advance. Most shut-in clauses refer to the expiration of the year as the reference point on which the well must be shut-in. Presumably this reference was included to ensure that a lessee did not have to make multiple shut-in payments during alternating periods of production and non-production. However, in a shut-in clause similar to Example 1, the insertion of the reference "at the expiration of the year" might be construed as a condition precedent to the payment of a shut-in royalty, because Example 1 starts out with the word "If". An argument could be raised that the lessee must wait until the end of the year to determine "If at the expiration of any year ... there is a well ... from which leased substances are not produced . . ." before it is entitled to make a shut-in payment. The counter-argument would be that the words "on or before such anniversary date" which occur later in the clause contemplate an advance payment. To avoid any potential problem, the shut-in clause should be drafted to provide that the lessee has the right to tender the payment prior to the expiry date.

Some clauses, such as Example 2, are drafted to provide a certain period of time after the shutting-in of the well in which to elect to make the shut-in payment. It would appear that a payment made within this time period would continue the lease, even if the payment was not made before the expiry of the primary term. Since the payment, when made, relates back to the date on which the well was shut-in, the inference is that the lease remains in force in the interim. To ensure that the lease continues, Example 2 could be redrafted to state that "if a well is shut-in, the lease shall remain in force for sixty days and the lessee may pay or tender to the lessor a shut-in royalty payment within such sixty days to cover the period from the date the well is shut-in until the next anniversary date".

\section{Shut-in Payments When Well Is Drilling Over The End Of The Primary Term}

At an early stage in the development of the freehold lease, it became evident that it was necessary to provide for the situation where the lessee had commenced drilling operations during the primary term but had not completed them at the expiry of the primary term. In order to allow the lease to be extended and allow the lessee to complete the drilling, "continuous drilling clauses" were included in the lease. Usually the continuous drilling clauses appear in the third proviso to the habendum in the lease. Although these clauses were intended to provide for a somewhat unique situation, a review of the authorities indicates that lessees have relied on them a great number of times. The tendency for lessees to defer drilling until the last possible moment has been increasing as gas markets have continued to deteriorate. If a lessee knows that any

67. Freeman v. Magnolia Petroleum Ltd. 171 S.W. (2d) $339^{\circ}$ (Tex 1943). 
well that is completed will be shut-in because of a lack of market, there is no economic justification to drill a well early in the term of the lease. However, by waiting until the last possible moment, the lessee must properly construe the third proviso to the habendum and the shut-in clause to ensure that the lease remains in force.

The first Canadian case to examine the relationship between the continuous drilling clause and the shut-in clause was Canadian Superior Oil Ltd. v. Paddon-Hughes Development Co. Ltd. and Ralph Hambly.68 The lease was dated June 17, 1948 and had a ten-year term with an "optional' type shut-in clause. The continuous drilling clause stated:

12. If Lessee shall commence to drill a well within the term of this lease or any extension thereof, Lessee shall have the right to drill such well to completion with reasonable diligence and dispatch, and if oil or gas be found in paying quantities, this lease shall continue and be in force with like effect as if such well had been completed within the term of years herein first mentioned.

Drilling commenced on June 10, 1958, and drilling and completion operations continued until August 6, 1958. A shut-in payment was made on August 13, 1958. The Supreme Court of Canada held that the continuous drilling clause extended the lease only until the well was completed, and that the shut-in royalty had to be paid before that date. While the Court did not decide which exact physical operation constituted the "completion of the well", it found that payment on August 13 was too late.

While the Hambly case involved a 1948 form of lease, the case of Kissinger Petroleums Ltd. v. Keith McLean Oil Properties Ltd. and Falcon Resources ${ }^{69}$ involved the interpretation of a 1970 lease. The shutin clause was of the "optional" type and was identical to Example 1. The lease in the Kissinger case contained the continuous drilling clause as part of the third proviso to the habendum. The third proviso was identical to that found in most current leases and stated:

\begin{abstract}
AND FURTHER ALWAYS PROVIDED that if at the end of the said Ten (10) year term the leased substances are not being produced from the said lands and the Lessee is then engaged in drilling or working operations thereon, or if at any time after the expiration of the said Ten (10) year term production of the leased substances has ceased and the Lessee shall have commenced further drilling or working operations within Ninety (90) days after the cessation of said production, then this Lease shall remain in force so long as any drilling or working operations are prosecuted with no cessation of more than Ninety $(90)$ consecutive days, and, if they result in the production of the leased substances or any of them, so long thereafter as the leased substances or any of them are produced from the said lands; provided that if drilling or working operations are interrupted or suspended as the result of any cause whatsoever beyond the Lessee's reasonable control, or if any well on the said lands or on any spacing unit of which the said lands or any portion thereof form a part, is shut-in, suspended or otherwise not produced as the result of a lack of or an intermittent market, or any cause whatsoever beyond the Lessee's reasonable control, the time of such interruption or suspension or non-production shall not be counted against the Lessee, anything hereinbefore contained or implied to the contrary notwithstanding . . . .
\end{abstract}

In the Kissinger case, the lease was dated March 6,1970 and was for a ten-year primary term. Kissinger commenced drilling on March 1, 1980 and tendered a payment to the lessor on March 4,1980. On the date that the payment was made, the well was still being drilled, the well depth was

68. Supran. 29.

69. Supra n. 57. 
only about two-thirds of the total depth and no oil or gas had been encountered in the well. Drilling operations continued until March 11, 1980 and on this date Kissinger advised the lessor by letter that the payment tendered on March 4, 1980 was to act as a shut-in royalty payment.

One of the main issues involved in the case was whether a shut-in payment could be tendered in advance of the existence of a shut-in well. However, both the decision of Mr. Justice Waite at trial and the unanimous decision of the Court of Appeal written by Mr. Justice McDermid raise the question whether any shut-in payment was required at all. There is certainly a suggestion in these decisions that the third proviso may grant the lessee an indefinite extension of the lease without the necessity of making any shut-in payments whatsoever.

As the well was being drilled over the expiry date of the primary term, the third proviso was applicable to extend the lease as long as drilling operations were prosecuted with no cessation of more than ninety consecutive days. However, Mr. Justice McDermid focused on the second part of the third proviso, which is a proviso to the third proviso itself, and stated:70

Was the lease, notwithstanding, continued by the words "provided that . . . if any well on the said lands . . . not produced as the result of a lack of or an intermittent market . . . the time of such ... non-production shall not be counted against the Lessee, anything hereinbefore contained or implied to the contrary notwithstanding'? The only meaning I can give this wording is that the time of non-production is not to be counted. Therefore, you have a well on the lands which is eventually to be produced when there is a market. It is the same as if the well had been completed and produced, for the hiatus between completion and production is not to be counted. For the purposes of the clause, the well should be considered as producing from its completion.

In the trial decision, Mr. Justice Waite stated:71

Actual production did not occur because of the lack of, or an intermittent, market for the gas. Accordingly, since the last portion of the third proviso prevents the period of non-production being "counted against the lessee", the lease would be extended until production could occur or resume.

These passages suggest that no shut-in payment would be required where the third proviso applies. However, both Mr. Justice McDermid and Mr. Justice Waite examined the further issue, namely, whether the shut-in payment tendered by Kissinger was valid. Presumably, if the lease was continued indefinitely without any payment, this further analysis would have been unnecessary. In light of these apparently conflicting factors, the actual position of the lessee remains somewhat unclear.

It is suggested that a lessee must make a valid shut-in payment in order to preserve the lease, because in the third proviso the phrase "the time of such ... non-production shall not be counted against the Lessee" does not apply to the situation when a shut-in well results from the drilling of a well over the expiry date of the primary term. If the second part of the third proviso was to be interpreted as extending the term of the lease indefinitely, it would lead to the anomaly that the conscientious lessee who drilled and completed its well before the expiry of the primary term would have to pay shut-in payments to extend its lease, but the lessee who delays its drilling and, accordingly, has to continue drilling over the ex- 
piry of the primary term, would be entitled to have its lease continued without making any such payment.

The third proviso of the habendum is meant to deal with two distinct situations:

(a) where drilling or working operations are being engaged in at the end of the primary term; and

(b) where production ceases after the expiry of the primary term.

In situation (b), the lessee must commence drilling or working operations within ninety days of cessation of production in order to continue the lease. When the lessee commences the required operations under situation (b) or is engaged in drilling or working operations under situation (a), it is required to prosecute each of these operations with no cessation of more than ninety consecutive days. Thus, in situation (b), the lessee has a ninety-day period in which to commence further operations and, once commenced, the lease will continue so long as there is no cessation in operations of more than ninety consecutive days. While there are two ninety-day periods in situation (b), there can only be one in situation (a), because the lessee must be engaged in drilling or working operations at the time of the expiry of the primary term. In situation (a), the lessee has no ninety-day period in which to commence the operations.

The second part of the third proviso which gives rise to the problem is as follows:

... provided that if drilling or working operations are interrupted or suspended as the result of any cause whatsoever beyond the Lessee's reasonable control, or if any well on the said lands or on any spacing unit of which the said lands or any portion thereof form a part, is shut-in, suspended or otherwise not produced as the result of a lack of or an intermittent market, or any cause whatsoever beyond the Lessee's reasonable control, the time of such interruption of suspension or non-production shall not be counted against the Lessee, anything hereinbefore contained or implied to the contrary notwithstanding ....

It is a complicated provision chiefly because it attempts to deal with both the (a) and (b) situations, as demonstrated by its repeated use of the word "or". However, it is submitted that the second part should be broken down into its two components as follows:

(i) provided that if drilling or working operations are interrupted or suspended ... the time of such interruption or suspension ... shall not be counted against the lessee.

(ii) provided that if any well on the said lands . . . is shut-in, suspended or otherwise not produced . . . the time of such . . . suspension or non-production shall not be counted against the lessee.

The wording under (i) applies to both situations (a) and (b), because both may involve drilling or working operations. However, (ii) can apply only to situation (b), because (b) is the only case which involves a cessation of production. Thus, the intent and purpose of (ii) is to relieve the lessee from having to commence additional drilling or working operations within ninety days of the cessation of production if the reason for the cessation was beyond the lessee's reasonable control.

It is also suggested the phraseology "the time . . . shall not be counted against the Lessee" is not language which is appropriate to continue the lease in force. It is, however, consistent with the suspension of the time 
period within which the lessee would otherwise be required to take some action. If the intention had been to extend the lease under these conditions, surely express words of grant or extension would have been used. For example, in the first part of the third proviso, the wording is "then the lease shall remain in force".

There do not appear to be any American authorities on this issue, probably because American leases generally do not contain wording similar to the second part of the third proviso in their continuous drilling clauses.

On the assumption that payment of a shut-in payment is required, the next issue is when is the payment required to be made. The third proviso provides that the "lease shall remain in force so long as drilling or working operations are prosecuted with no cessation of more than ninety (90) consecutive days"'. While it is beyond the scope of this paper to attempt to define what is meant by "drilling or working operations", it is clear that as long as they are occurring the lease continues. The phrase "with no cessation of more than ninety (90) consecutive days" was probably designed to avoid any problems with temporary interruptions in the operations. However, similar phrases have been interpreted in the United States to extend the lease even after all operations have been completed.

In Skelly Oil Company v. Harris, ${ }^{72}$ the lessee drilled over the October 21,1953 expiry date of the primary term. On November 24, 1953, drilling operations were finished and the gas well was completed and capped. Production of gas began on January 4, 1954. The continuous drilling clause provided that "the lease shall remain in force so long as operations are prosecuted with no cessation of more than sixty (60) consecutive days". The Texas Supreme Court rejected the lessor's contention that the sixty-day clause had no further application after the lessee had completed a well capable of production. The lessor had maintained that the only purpose of the sixty-day clause was to prevent termination of the lease during any brief periods that might be required by the lessee to make tests, decisions and alterations in equipment in an attempt to complete the well as a producer. The Court decided that the ordinary and commonly accepted meaning of "cessation" was either a temporary or a final ceasing. Thus, the lease was extended for a further sixty-day period after operations finally ceased. As actual production occurred some forty-one days later, the lease remained valid. A similar approach was taken in Duke et al v. Sun Oil Company et al. ${ }^{73}$ This case decided that the sixty day cessation clause allowed the lessee to tender a shut-in royalty payment within sixty days of the shutting in of a well that had been drilled over the expiry of the primary term. Shut-in clauses which provide for retroactive payments (Example 2) may extend the lease for an even further period. ${ }^{74}$

It would thus seem that the Canadian lessee who drills over the expiry of the primary term is in a fairly strong position. If the dicta in Kissinger are adopted, perhaps no shut-in payment is required at all. Even if pay-

72. 352 S.W. (2d) 950 (Tex S.C. 1962).

73. 320 F. (2d) 853 (C.A. Sth Cir 1963).

74. See discussion supra at Part III. C. 2. 
ment is required, there will usually be a ninety-day period in which to tender it after the final act of shutting in the well.

\title{
4. Shut-in Payments When Production Ceases After The Expiry Of The Primary Term
}

The three previous sections have dealt with the situation where a well is shut-in immediately and has never been produced. However, the issue of when a shut-in payment is required when production ceases after the expiry of the primary term is directly linked to the situation of a shut-in well which results from the drilling of a well over the expiry of primary term. This is because both situations are governed by the third proviso to the habendum.

While it is not necessary to repeat all the observations previously made, it should be recognized that the results of the Kissinger case are directly applicable to this situation. Under one interpretation of the Kissinger case, it could be argued that no shut-in payment is required. However, under the author's suggested interpretation, the purpose of the second part of the third proviso is simply to provide the lessee with an alternative method of extending the lease when production ceases. That alternative method requires the payment of a shut-in payment.

The portion of the third proviso covering the cessation of production situation provides:

\begin{abstract}
... if at any time after the expiration of the said term production of the leased substances has ceased and the Lessee shall have commenced further drilling or working operations within ninety (90) days after the cessation of said production, then this Lease shall remain in force so long as drilling and working operations are prosecuted with no cessation of more than 90 days. [emphasis added.]
\end{abstract}

The only method contemplated by the initial portion of the third proviso is the commencement of further operations. Clearly, this would be unnecessary if the cessation of production was caused by the shutting in of a well for a lack of market. The language of the second part of the third proviso, "the time of such non-production shall not be counted against the Lessee", simply relieves the lessee of having to commence further operations in order to continue the lease. However, as there is nothing to state that the lease remains in force during this interval, a shut-in payment must be made to constitute "deemed production" and satisfy the habendum. Once again, the exact date on which the shut-in payment is required will depend on whether the cessation of production is temporary and whether the shut-in clause provides for retroactive payments.

\section{WHAT CONDITIONS MUST BE PRESENT BEFORE A SHUT- IN PAYMENT CAN BE CONSIDERED VALID?}

This part of the paper will deal with the various conditions which must be present before a shut-in payment can be validly tendered. While most of the conditions are contained in the specific shut-in clause, other conditions arise because of the relationship with other terms of the lease. While the specific wording of the shut-in clause must be examined before a definitive list of the conditions which must be satisfied can be made for any shut-in clause, the following general comments may be useful in interpreting the requirements: 


\section{Must A Well Be Capable Of Producing In Paying Quantities?}

Usually, a shut-in clause does not specify that a well has to be capable of producing in paying quantities in order for a shut-in payment to be made. United States courts, in interpreting the word "production" in the habendum, have concluded that it requires production in paying quantities. ${ }^{75}$ Similarly, various U.S. courts have held that the concept of "deemed production" should also be linked to production in paying quantities, and that, therefore, a well which cannot produce in paying quantities cannot be used as the basis for a shut-in payment. ${ }^{76}$ This is a logical conclusion, because the purpose of the shut-in clause is to deem production for the purposes of the habendum.

\section{What Reasons Justify the Shutting-In of a Well?}

Shut-in clauses contain a variety of reasons for justifying the act of shutting-in the well:

Example 1:

... not produced as a result of a lack of or an intermittent or uneconomical or unprofitable market or any cause whatsoever beyond the Lessee's reasonable control. . . .

Examples 2 and 3:

... not being produced, as the result of a lack of or an intermittent market or any cause whatsoever beyond the Lessee's reasonable control. . . .

Example 4:

... no leased substances are being produced as a result of the lack of an economical or profitable market. . . .

Common Current Lease:

... if all wells on the said lands are shut-in suspended or otherwise not producing. . . .

The last example is becoming quite common in Canadian leases and is very favorable to the lessee, since it does not set out any requirements that must be met to justify the shut-in payment. However, the lessee who has a shut-in clause similar to that contained in Example 4 may be faced with some difficult questions given the current gas market situation in Alberta, since this clause requires that the well be shut-in for the lack of an "economical or profitable" market. These terms are highly subjective, and, although space does not permit an analysis of these problems, it is useful to note a few of the potential problem areas. Does a lessee have to attempt to sell its gas into the Alberta discount market or can it shut-in a well and await a full-price contract? Must a lessee make every attempt to share any gas contracts on adjoining properties, including applying to the Energy Resources Conservation Board for a common purchaser order if necessary? What happens to a shut-in well when the reserves for that well are cross-dedicated to a producing well?

The shut-in clauses in Examples 1, 2 and 3 expand the reasons for shutting in the well from solely market-related reasons to any other causes beyond the lessee's reasonable control. However, given the strict interpretation of a similarly-worded force majeure clause in Canada-Cities

75. Supra n. 6 at s. $26.4,26.8$ (c).

76. Taylor v. Kimbell 54 So. (2d) 1 (La. 1951), Kidd v. Hoggett 331 S.W. (2d) 515 (Tex. Civ. App. 1959), Hoyt v. Continental Oil Company 606 P. (2d) 560 (Okla. 1980). 
Service Petroleum Corp. v. Kininmouth, ${ }^{7}$ the lessee may find it difficult to rely on this language. In that case, a majority of the Alberta Court of Appeal was of the view that road bans and orders of the Energy Resources Conservation Board were not matters beyond the reasonable control of the lessee, because both the occurrence of road bans and the requirements of the Conservation Board were known and should have been anticipated.

\section{Can A Shut-In Payment be Tendered Prior to the Existence of a Shut-In Well?}

Given that three Canadian decisions have held that the leases had terminated because of the late payment of shut-in royalty, ${ }^{78}$ it is easy to see why a lessee would wish to make its payment at the earliest possible moment. Difficulties may arise, however, when the lessee makes the payment in anticipation of a shut-in well. This issue was addressed in the Kissinger case. ${ }^{79}$

In the Kissinger case, the shut-in payment was tendered while the well was still being drilled. The top lessee argued that the wording of the shutin clause (Example 1) made the existence of a well a condition precedent to the right of the lessee to make the shut-in payment. As the payment had been tendered before the lessee had encountered any oil or gas in the well, the top lessee's position was that the condition had not been met.

After the well had been shut-in on March 11, 1980, the lessee notified the lessor that the payment previously made on March 4, 1980 would act as the shut-in royalty. Mr. Justice McDermid appears to have relied on this subsequent designation of the earlier payment to uphold the validity of the lease: 80

I find nothing which decides or suggests that a payment which is made by a lessee in advance of the completion of the well, and in anticipation that the well will be capable of commercial production, is not in compliance with the shut-in royalty clause when upon completion of the well it is designated as a shut-in royalty payment and accepted by the lessor as such. What the position would be if the lessor refused the payment is a question I do not have to decide. Here it was accepted and the lessee's subsequent designation was not objected to by the lessor.

The Trial Judge, Mr. Justice Waite, also thought that an advance payment made in contemplation of a future shut-in well did not impair its efficacy as a shut-in royalty payment.

It would appear that a lessee can probably tender a shut-in payment before the well is in existence, as long as it is made in anticipation that a well will be capable of commercial production. If the well results in a dry hole, the advance payment cannot continue the lease, because the requirement of a well capable of producing in paying quantities has not been met. Given the protection of other clauses, such as the continuous

77. [1964] S.C.R. 439, 34 W.W.R. 392 (Alta. C.A.).

78. Canadian Superior Oil of California Ltd. v. Kanstrup, supra n. 38; Canadian Superior Oil Ltd. v. Murdoch, supra n. 58; Canadian Superior Oil Ltd. v. The Paddon-Hughes Development Co., supran. 29.

79. Supra n. 57.

80. Id. at 689 (Alta. C.A.). 
drilling clause and perhaps the third proviso to the habendum, it is unlikely that a lessee will have to make a payment in advance of a shut-in well being in existence. However, for added caution, the lessee should always follow the advance payment with a subsequent notification as was done in the Kissinger case. 